\title{
Determinants of Undergraduate Students' Attitude and Perception towards the Use of Electronic Information Resources (EIRs) among Undergraduate Students in Selected Universities in Eastern Cape, South Africa
}

\author{
Oluwayemi Ibukun Oluwa Olatoye ${ }^{1 *}$, Fhulu Nekhwevha ${ }^{2}$, Ndakasharwa Muchaonyerwa1 \\ ${ }^{1}$ Department of Library Information Science, Faculty of Social Science and Humanities, University of Fort Hare, Alice, \\ South Africa \\ ${ }^{2}$ Department of Sociology, Faculty of Social Science and Humanities, University of Fort Hare, Alice, South Africa \\ Email: *yolatoye19@gmail.com
}

How to cite this paper: Olatoye, O.I.O., Nekhwevha, F. and Muchaonyerwa, N. (2020) Determinants of Undergraduate Students' Attitude and Perception towards the Use of Electronic Information Resources (EIRs) among Undergraduate Students in Selected Universities in Eastern Cape, South Africa. Open Access Library Journal, 7: e6094.

https://doi.org/10.4236/oalib.1106094

Received: January 20, 2020

Accepted: February 24, 2020

Published: February 27, 2020

Copyright $\odot 2020$ by author(s) and Open Access Library Inc.

This work is licensed under the Creative Commons Attribution International License (CC BY 4.0).

http://creativecommons.org/licenses/by/4.0/

cC) (i) Open Access

\begin{abstract}
This study sought to investigate the attitudinal behavior and perceptions of undergraduate students in University of Fort Hare and Rhodes, towards their utilization of e-information resources (EIRs). The essence was to ascertain whether their attitude and perception have a positive or negative impact on e-resource use in selected universities in Eastern Cape, South Africa. The purposive and proportionate stratified random sampling techniques were employed in selecting the study population and sample size while questionnaire and oral interview were used as instruments for data collection. The findings revealed that the respondents usually encounter difficulties which negatively influence their attitudes and behavior towards e-resource use. They assume that additional special computing skills are required before one can be competent enough to effectively utilize these resources. In carrying out this research, a total of 377 copies of the questionnaire were randomly distributed to undergraduate students in all the faculties of both institutions, and the results were analyzed using the Statistical Package of the social Sciences (SPSS Version 32). Additionally, hypotheses were tested in order to validly make assertions based on the collected data, and the results state that perception and attitude of undergraduate students affect their utilization of E-journals. Recommendations were made, and these include the need for mass enlightenment campaign on the use and benefits of E-resources among undergraduate students through training and re-training, seminars, and workshops.
\end{abstract}




\section{Subject Areas}

Information Science, Library, Intelligence and Philology

\section{Keywords}

Electronic Information Resources (EIRs), Attitudes and Perception, University of Fort Hare, University of Rhodes, Undergraduate Students

\section{Introduction}

The impact of E-resources is now ubiquitous across the globe. The e-resources are valuable in the academic community with the aim of enhancing academic productivity. In the African continent, electronic information resources are very useful to students because they help them to access relevant, remote and germane information, students can interact and deliberate on important academic issues by means of interactive chats and video conferences. Information resources provide students in HEIs with several prospects compared to their forerunners. It is on this premise that [1] [2] [3] opined that reading an e-journal is different from a printed one. In recent years, [4] [5] disclosed that e-information has progressively developed into a vital resource in every institution of learning. The progress and multiplicity of electronic resources, especially e-journals, in the past decade have led to the reduction of printed journals [6] [7]. Further, [8] contends that technological development resulted in the delivery of new horizons for creating, storing, accessing distributing and presenting information. The impact of moving from text-based to resource-based learning has involved heavier use of library resources and a higher demand for diverse media sources [9], and this has culminated in the delivery and utilization of digital resources in Higher Education Institutions (HEIs) [10]. E-information reading a printed version, many users ascertain the likelihood that electronic materials provide users with advanced functionality features beyond what is achievable in printed format.

Preference of electronic information resources entails not only the issues around financial and physical access to the widest range of people and localities, but also includes having all groups in society seeing the relevance and potential of gaining from them, and their meaningful contents. The sources of electronic information resources include the laptop, phone, cyber café, library, personal computer, departmental laboratory or libraries. Access to these sources can be through home, school, and work place or through a range of community locations, and this to a large extent helps to determine the preference of particular electronic information resources. Indeed, accessibility to these services has become an important issue. This is due to the fact that we live in a rapidly changing society, where information is power and accessibility to it is a fundamental human right [11]. 
Universities do not deny legitimate access to information by any student, but recognize that such a resource may be open to misuse and abuse. While the internet contains a wealth of valuable and interesting information, some of this information may be inaccurate, out of date, controversial, false, offensive and/or illegal. Therefore, it is the undergraduate students' responsibility to ensure that they exhibit the right attitudes and perception towards the use of information you discover on electronic information resources. According to [12], HEIs need to advance in multifaceted plans for ensuring that students' rights and freedom of information are protected and respected, while both lawful and procedural safeguards offer some declaration to students that HEIs internet usage is educationally sound. Nevertheless, [13] revealed that student's expectation of finding information on digital resources is not a straight forward matter. He opined that that student without prior knowledge of particular protocols, when engaging search terms and keywords will face obstruction in accessing information. According to [14], he stated that one of the reasons why students prefer digital technology is because it provides instant access to information from a multiplicity of choices, and this motivates the students to learn. In most African universities, undergraduates find electronic resources useful as they help them to have access to unimaginable resources or information. This, on the other hand, has helped them in overcoming the problem of scarcity of new books in the library.

Many students in universities find electronic information resources useful because they are time-saving. [15] opined that students access the internet for different purposes such as to supplement notes given to them by lecturers, to complete class assignment, write projects and to communicate via e-mail. In this regard, [16] disclosed that there exits an increase in service delivery and exploitation of e-information resources because of the unavailability of the traditional print format. More reasons given for the student's use of electronic resources in universities is that many students depend upon the internet and electronic journals, because publications appear with mixed media features in a complete electronic format [17]. This is equally supported by the fact that their features fascinate students. In a bid to guide against being left behind by the opportunities created by electronic information resources, students work hard to adopt the latest skills and techniques required for their maximum usage of electronic information resources for their academic work in their institutions. It is important to note at this juncture that the undergraduate students use electronic information resources and services much more than any other category of students in the university. This is because they are presumed to be computer literate, considering the impact of the computer age on them [18]. This is supported by [19] in their opinion that the vast majority of undergraduates of all categories turn to the computer services like the internet for their academic work. Also, in support of this notion, [20] stated that "the way undergraduates who were once used to read through books page by page have now turned to the internet for their academic needs is unimaginable". [21] reiterated that undergraduates of all categories in one way or the other use computer and other electronic information re- 
sources for their academic work. According to [13], he stated that undergraduates of both sexes in one way or the other cherish electronic information resources and internet services much more than any other category of students in the university.

\section{Literature Review}

E-Information resources have developed to a vital part of HEI collections and services; therefore, several relevant researches have been done on attitudes regarding the utility of digital resources by undergraduate students in their educational institutions. Further, perception is an active process, as one selectively perceives, organizes and interprets what one experiences. Interpretations are based on the perceiver's past experiences, assumptions about human behaviour, knowledge of the other circumstances, present moods/wants/desires and expectations." According to D. Scott, "Perception is a discerning procedure which is capable of sensing much more data than the brain is capable of handling. Six factors which enhance selectivity are background, concreteness, extensity, intensity, velocity, contrast, and impressivity". Perception is not only comprising of stimulus variables that make up the perception of our environment-like sounds, colours, shapes, textures, etc. but other variables too which exist in within the perceiver. Perception (which originates from the Latin word perceptio) is the organization, documentation, and understanding of sensory information in order to characterize and understand the environment [22]. All perception involve signals in the nervous system, which emanate from physical or chemical stimulation of the sense organs. For example, vision involves light striking the retina of the eye, smell is facilitated by odour molecules, and hearing involves pressure waves. Perception is not the passive receipt of these signals, but is shaped by learning, expectation, memory, and attention [22].

Studies have addressed the two concepts of attitude and perception towards electronic resources. [23] discussed attitude in general as the individuals' responses in preferential ways as a result of their beliefs. The precise definition related to this study was defined by [24] who referred to it as the students' reactions to exploring digital resources on account of their beliefs, their assumptions, and people's sentiments. Moreover, [23] described student attitudinal behavior in the academic environment as the electronic resources evaluation in either positive or negative manners that influence the respondents learning process. Hence, attitudinal behavior and perception towards the exploration of digital resources is simply the propensity that the student adapts either, positively or negatively, for using the digital resources of the library. On the other hand, the second concept of the study of EIR is what [25] defined as "material (data or programs) encoded for manipulation by computerized device, and this material may require the use of a peripheral device directly connected to a computerized device". In addition, reviews and studies that addressed attitude and perception of electronic information concepts, there are empirical studies that have investi- 
gated the correlation between attitudinal behavior and perception of students, faculty, researchers, and librarians toward using the electronic resources, information services, and using the library. [24] conducted a recent study that investigated students' attitude toward electronic resources. The study indicated that EIR was under-utilized in general because of the negative attitude of the students towards the use of library electronic resources. [8] piloted a study to comprehend the perception and management of digital resources, and established that students preferred using the library website and internet to recover significant materials. Furthermore, the major challenges encountered by students during the search process are the lack of ability to retrieve relevant material, on account of the ambiguous search methods, and slow internet connectivity, and this conforms to the theoretical framework that was utilized in this research.

Aim of the study: This study aims at investigating the attitudes and perceptions of undergraduate students towards the use of electronic information resources (EIRs) in the Universities of Fort Hare and Rhodes, Eastern Cape, South Africa.

\section{Methodology}

In carrying out this research, a total of 377 copies of the questionnaire were randomly distributed to undergraduate students in all the faculties of both institutions (260 in UFH and 117 copies in RU respectively). Further, this research utilized the five-point Likert scale in the measurement, evaluation and assessment of the questionnaire items relating to attitudes and perceptions of undergraduate students in relation to electronic resources use. The study utilized the Likert scale, which allows respondents to select a choice that best demonstrates their level of agreement with a given statement, and out of the 377 questionnaire copies distributed, 266 copies were returned, giving a response rate of $70.6 \%$. The results were analyzed using the Statistical Package of the social Sciences (SPSS Version 26).

\section{Adopted Framework for This Study}

The adopted framework for this study exemplifies the postulation of the theoretical framework underpinning this study, namely TAM, DOI and TRA, because the models depict the variables utilized in this study, thus, the adopted research framework for this study is exemplified in Figure 1 below.

This framework depicts the key factors for the utilization of e-information resources among the undergraduate students in the selected HEIs. From the diagram, before an electronic resource is utilized, there must be awareness and acceptance of the resource, hence, the perceived usefulness is dependent on the awareness of electronic resources, leading to the attitudinal behavior to utilize e-information resources. This explains further that the negligence of the undergraduate students on the utilization of e-information resources depends on their perception and attitudes to the use of the e-resources, which is still centered on 


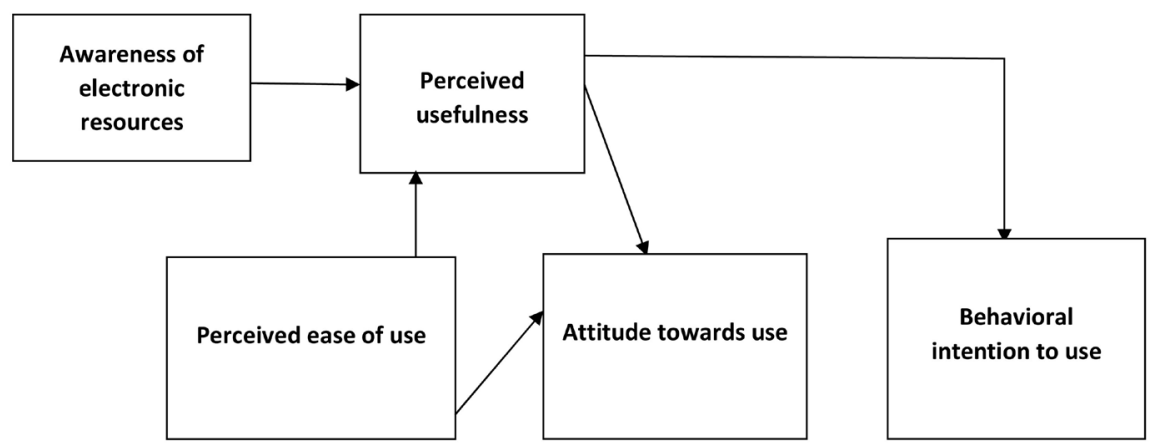

Figure 1. Adopted framework for the chapter (Source: Rogers, 1983).

perceived usefulness. This further explains that the attitudes and perception of the respondents depend on their utilization of e-information resources. This diagram is supported by TAM, TRA and DOI. Below are the findings of the study.

\section{Results and Discussion}

In Table 1, a preponderance of the surveyed respondents 101 (71.6\%) specified that they never utilized HINARI. On the contrary, 34 (18.1\%) of the surveyed UFH and RU respondents confirmed their usage of E-Journals every time, while 29 (15.6\%) of the respondents use E-books every time. JSTOR 94 (63.9\%), EbscoHost 88 (59.1\%), OARE 98 (71.0\%), DOAJ 81 (57.0\%), AJOL 92 (67.2\%) ScienceDirect 91 (46.9\%), ERIC 83 (60.1\%), SAGE 77 (52.7\%), PUBMED CENTRAL 85 (61.2\%), CD-ROMs 52 (34.0\%) and OPAC 40 (24.7\%) were never used by the respondents. Also, in the course of the in-depth research interview, most of the interviewees make use of CD-ROMs, E-JOURNALS and E-books to do their school assignments. The frequency in the utilization of e-information resources by the respondents is depicted in Table 1 and Figure 2 and Figure 3.

The research outcome for this study indicates that e-journals were widely used of e-information resources among the surveyed undergraduate students. This is because the statistics recorded from the table indicate that $51(27.1 \%)$ and 34 (18.1\%) respondents used e-journals almost every time and every time respectively. The reason for the utilization of e-information resources such as e-journals is its importance to the academic work of the undergraduate students. This viewpoint is also corroborated in empirical literature by [26] [27]. In the study of [28], he opined that the regularity as regards the utilization of e-information resources and service delivery of the same will match the level of awareness disclosed. Rather, regular frequency of daily utilization of e-information resources use and twice weekly accounted for 156 (52\%), while 99 or 33\% utilize the e-library within 2 - 3 hours daily. This simply means that as respondents engage in the utilization of e-information resources, the greater their proficiency levels. This assertion is also supported by [29]. Furthermore, [24] also shed more light on the frequency in the use of electronic resources by revealing that $38(24.1 \%)$ of the respondents he surveyed use e-journals weekly. In support of these findings, research hypothesis was tested on the attitude and perception of 


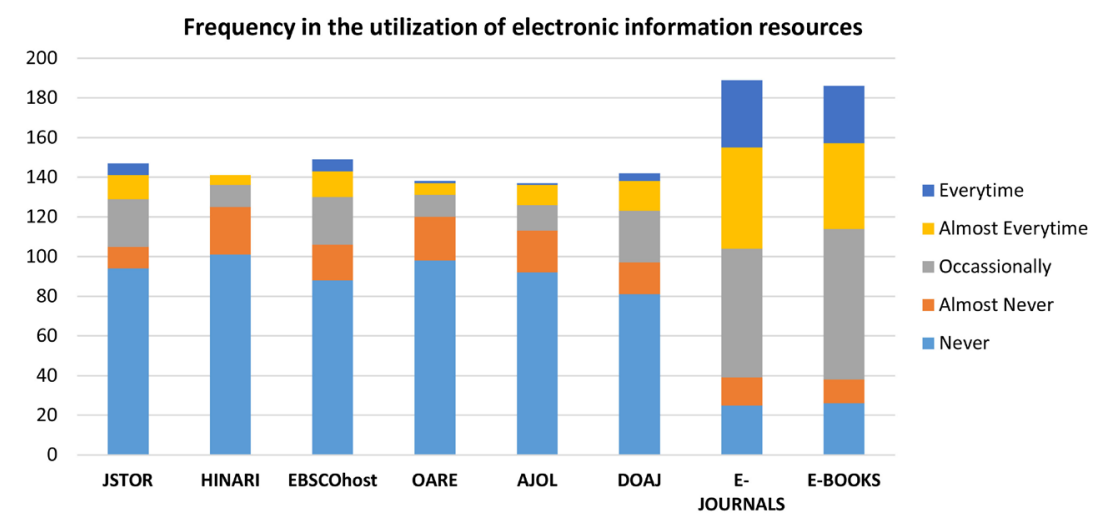

Figure 2. Chart showing the frequency in the utilization of e-information resources by the Respondents.

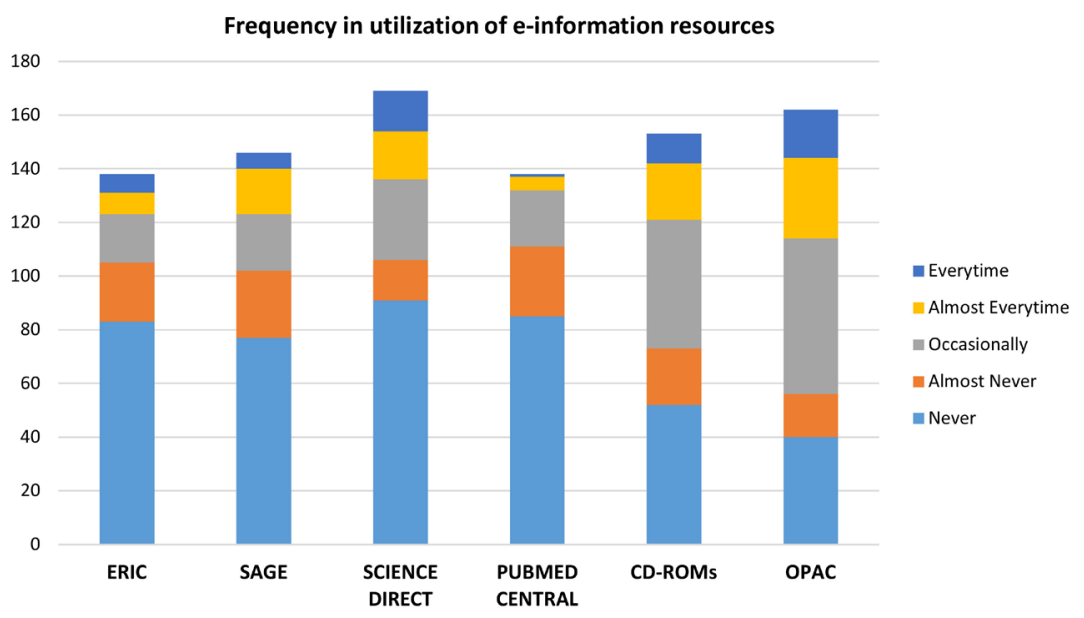

Figure 3. Chart showing the frequency in the utilization of e-information resources by the Respondents.

Table 1. Frequency in the utilization of e-information resources by the respondents.

\begin{tabular}{|c|c|c|c|c|c|c|}
\hline $\mathrm{S} / \mathrm{N}$ & Electronic Resources & Never & Almost Never & Occasionally/Sometimes & Almost Every time & Every time \\
\hline 1. & JSTOR & $94(63.9 \%)$ & $11(7.5 \%)$ & $24(16.3 \%)$ & $12(8.2 \%)$ & $6(4.1 \%)$ \\
\hline 2. & HINARI & $101(71.6 \%)$ & $24(17.0 \%)$ & $11(7.8 \%)$ & $5(3.5 \%)$ & \\
\hline 3. & EBSCOhost & $88(59.1 \%)$ & $18(12.1 \%)$ & $24(16.1 \%)$ & $13(8.7 \%)$ & $6(4.0 \%)$ \\
\hline 4. & OARE & $98(71.0 \%)$ & $22(15.9 \%)$ & $11(8.0 \%)$ & $6(4.3 \%)$ & $1(0.7 \%)$ \\
\hline 5. & AJOL & $92(67.2 \%)$ & $21(15.3 \%)$ & $13(9.5 \%)$ & $10(7.3 \%)$ & $1(0.7 \%)$ \\
\hline 6. & DOAJ & $81(57.0 \%)$ & $16(11.3 \%)$ & $26(18.3 \%)$ & $15(10.6 \%)$ & $4(2.8 \%)$ \\
\hline 7. & E-JOURNALS & $25(13.3 \%)$ & $14(7.4 \%)$ & $65(34.0 \%)$ & $51(27.1 \%)$ & $34(18.1 \%)$ \\
\hline 8. & E-BOOKS & $26(14.0 \%)$ & $12(6.5 \%)$ & $76(40.9 \%)$ & $43(23.1 \%)$ & $29(15.6 \%)$ \\
\hline 9. & ERIC & $83(60.1 \%)$ & $22(15.9 \%)$ & $18(13.0 \%)$ & $8(5.8 \%)$ & $7(5.1 \%)$ \\
\hline 10. & SAGE & $77(52.7 \%)$ & $25(17.1 \%)$ & $21(14.4 \%)$ & $17(11.6 \%)$ & $6(4.1 \%)$ \\
\hline 11. & SCIENCE DIRECT & $91(46.9 \%)$ & $15(10.2 \%)$ & $30(20.4 \%)$ & $18(12.2 \%)$ & $15(10.2 \%)$ \\
\hline 12. & PUBMED CENTRAL & $85(61.2 \%)$ & $26(18.7 \%)$ & $21(15.1 \%)$ & $5(3.6 \%)$ & $1(0.7 \%)$ \\
\hline 13. & $\begin{array}{c}\text { CD-ROM DATABASES } \\
\text { in the library }\end{array}$ & $52(34.0 \%)$ & $21(13.7 \%)$ & $48(31.4 \%)$ & $21(13.7 \%)$ & $11(7.2 \%)$ \\
\hline 14. & OPAC & $40(24.7 \%)$ & $16(9.9 \%)$ & $58(35.8 \%)$ & $30(18.5)$ & $18(11.1 \%)$ \\
\hline
\end{tabular}


undergraduate students on their utilization of e-information resources such as E-journals, in which the test result was significant at $(p \leq 0.05)$. In the course of this analysis, the table was scored from 1 - 5, which interprets as 1 -never and 5 -every time. The research hypothesis is stated below.

\section{Research Hypothesis}

$\mathrm{H}_{01}$ - There is no significant relationship between the perception and attitude of undergraduate students towards their utilization of E-journals. The regression analysis test of hypothesis three is given in Table 2 below.

The result in Table 2 above illustrates that there is significant correlation regarding the perception and attitude of undergraduate students towards the frequency and their utilization of e-information resources $(p \leq 0.05)$. This implies that the perception and attitude of undergraduate students of undergraduate students affect their utilization of E-journals. This research finding is supported in the studies of [15] [22], that positive attitude towards a behavior could influence actual behavior, such as in their utilization of e-information resources such as e-journals among the respondents. Also, this buttresses the empirical study of [24] that it is imperative to comprehend attitude towards e-journals usage. The purpose for e-resources use is stated below.

\section{Purpose for Use of Electronic Resources}

In Table 3 below, most of the respondents 143 (62.7\%) indicated that they use electronic resources to do school work. Also, 81 (38.0\%) of the surveyed respondents confirmed that they utilize e-information resources to chat with people while 115 (51.8\%) of the respondents use E-Resources to obtain course-related information. In addition, 69 (32.2\%) of the respondents were neutral in their use of E-Resources in listening to sport news, while 61 (28.2\%) of the undergraduate students surveyed use E-Resources to download music and video. Also, in the course of the in-depth research interview, over $70 \%$ of the interviewees make use of electronic resources mainly to obtain course-related information and entertainment purposes. The specific use of e-resources for different purposes is stated in Table 3 and Figure 4 and Figure 5 below.

Table 2. Relationship between perception and attitude of undergraduate students towards their utilization of E-journals Coefficients.

\begin{tabular}{|c|c|c|c|c|c|}
\hline \multirow{2}{*}{ Model } & \multicolumn{2}{|c|}{$\begin{array}{l}\text { Unstandardized } \\
\text { Coefficients }\end{array}$} & \multirow{2}{*}{$\begin{array}{c}\begin{array}{c}\text { Standard } \\
\text { Coefficients }\end{array} \\
\text { Beta }\end{array}$} & \multirow{2}{*}{$\mathrm{T}$} & \multirow{2}{*}{ Sig. } \\
\hline & $\mathrm{B} /$ Std. & Error & & & \\
\hline (Constant) & 2.042 & 0.450 & & 4.535 & 0.000 \\
\hline Attitude & 0.384 & 0.138 & 0.208 & 2.778 & 0.006 \\
\hline $\begin{array}{c}\text { Dependent Variabl } \\
\text { E-JOURNALS }\end{array}$ & \multicolumn{4}{|c|}{ Dependent Variable: } & \\
\hline
\end{tabular}




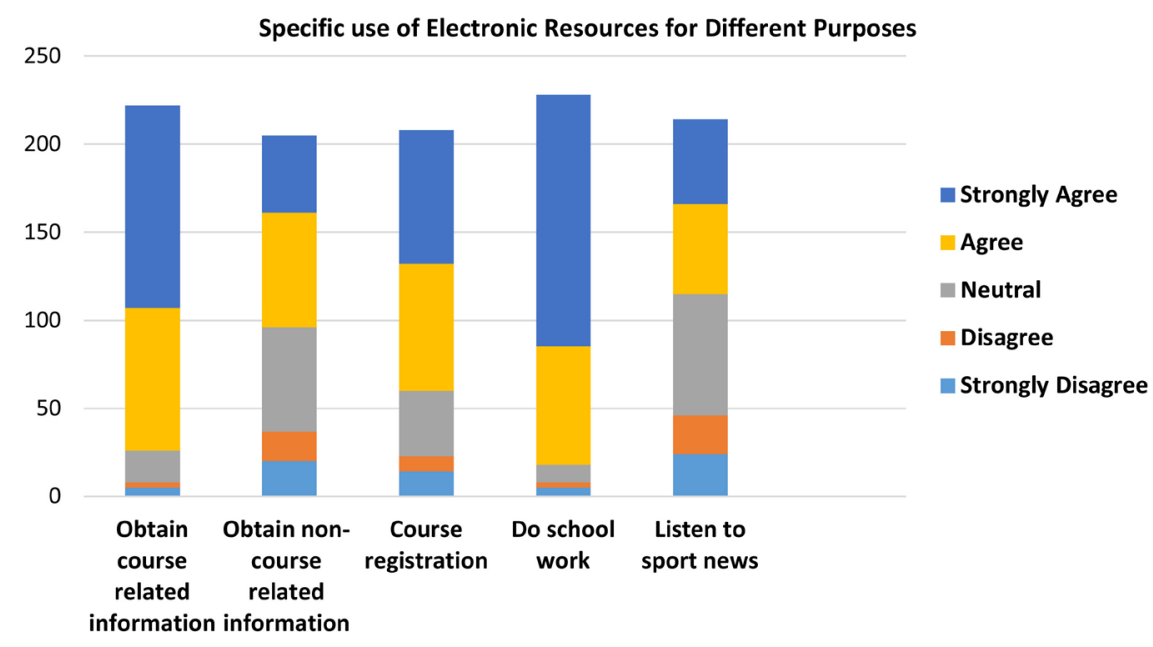

Figure 4. Chart showing the specific use of electronic resources for different purposes.

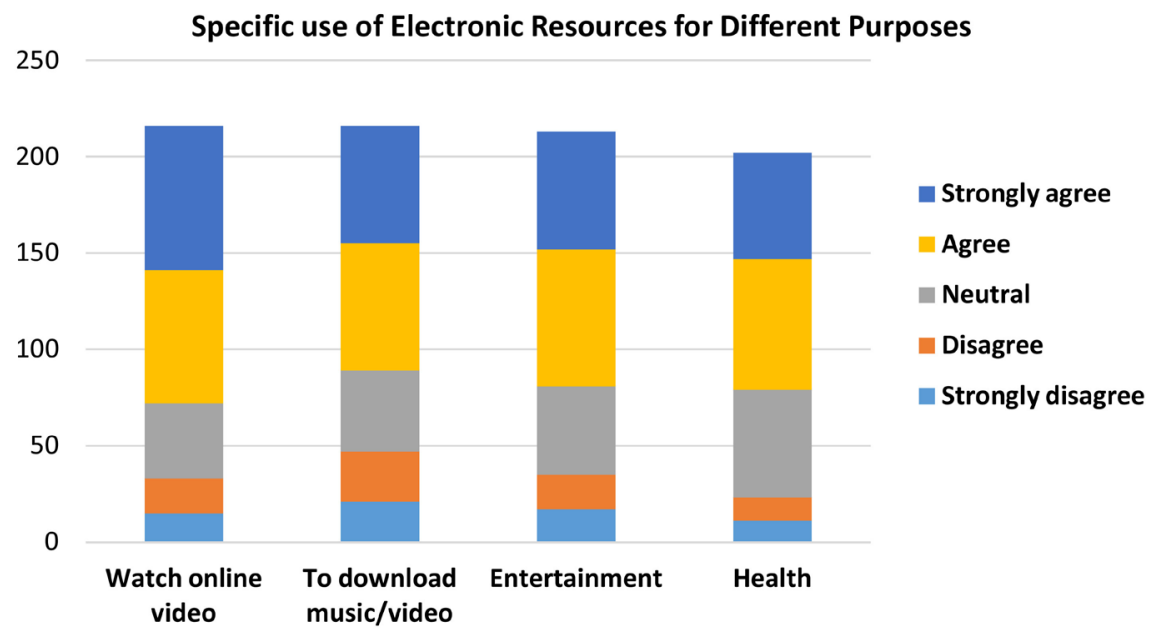

Figure 5. Chart showing the specific utilization of e-information resources for different purposes.

Table 3. Specific use of electronic resources for different purposes.

\begin{tabular}{cccccc}
\hline Purpose of utilizing of e-information resources & Strongly disagree & Disagree & Neutral & Agree & Strongly agree \\
\hline $\begin{array}{c}\text { Obtain course-related information } \\
\text { (research education) }\end{array}$ & $5(2.3 \%)$ & $3(1.4 \%)$ & $18(8.1 \%)$ & $81(36.5 \%)$ & $115(51.8 \%)$ \\
$\begin{array}{c}\text { Obtain non-course related information } \\
\text { (research education) }\end{array}$ & $20(9.8 \%)$ & $17(8.3 \%)$ & $59(28.8 \%)$ & $65(31.7 \%)$ & $44(21.5 \%)$ \\
Course registration & $14(6.7 \%)$ & $9(4.3 \%)$ & $37(17.8 \%)$ & $72(34.6 \%)$ & $76(36.5 \%)$ \\
$\quad$ Do school work & $5(2.2 \%)$ & $3(1.3 \%)$ & $10(4.4 \%)$ & $67(29.4 \%)$ & $143(62.7 \%)$ \\
Communicate by e-mail & $7(3.2 \%)$ & $6(2.7 \%)$ & $30(13.6 \%)$ & $83(37.6 \%)$ & $95(43.0 \%)$ \\
Chat with other people & $10(4.7 \%)$ & $14(6.6 \%)$ & $46(21.6 \%)$ & $62(29.1 \%)$ & $81(38.0 \%)$ \\
Listen to sport news & $24(11.2 \%)$ & $22(10.3 \%)$ & $69(32.2 \%)$ & $51(23.8 \%)$ & $48(22.4 \%)$ \\
Watch online video & $15(6.9 \%)$ & $18(8.3 \%)$ & $39(18.1 \%)$ & $69(31.9 \%)$ & $75(34.7 \%)$ \\
To download music and video & $21(9.7 \%)$ & $26(12.0 \%)$ & $42(19.4 \%)$ & $66(30.6 \%)$ & $61(28.2 \%)$ \\
Entertainment & $17(8.0 \%)$ & $18(8.5 \%)$ & $46(21.6 \%)$ & $71(33.3 \%)$ & $61(28.6 \%)$ \\
Health & $11(5.4 \%)$ & $12(5.9 \%)$ & $56(27.7 \%)$ & $68(33.7 \%)$ & $55(27.2 \%)$ \\
\hline
\end{tabular}


In the course of analyzing the results for Table 3 , the researcher observed that $143(62.7 \%)$ respondents utilize e-information resources for their academic work. On account of this observation, the purpose of providing the e-resource is justified. In correlation with this result, an empirical study conducted by [30] concluded in his study that students' utilization of e-information resources for school work is quite impressive. A study of HEIs revealed that students employ the fastest to satisfactory result when doing research. The attitudes and perception of the respondents are analyzed in Table 4.

The table above depicts the attitudes and perception of undergraduate students towards e-resources use. The result indicates that 89 (41.4\%) of the surveyed undergraduate students are of the opinion that E-Resources are readily available for use. The difficulties encountered in their utilization of e-information resources discussed in the subsequent section below.

\section{Difficulties Encountered in the Utilization of E-Information Resources}

In a bid to effectively utilize the ever-increasing array of e-information resources, students must ensure the acquisition and mastery of the skills essential for their exploitation. "for students using a variety of on-line database, it is as though they were parking lot attendants, where every vehicle is not only a different make and model but has a different configuration" [31]. In Figure 6 below, 57 (26.6\%) encountered too much information on the Internet, while 53 (24.9\%) respondents complained about high cost of Internet access. Furthermore, $35(16.7 \%)$ respondents were of the opinion that there were inadequate computer workstations. Also, $55(25.8 \%)$ respondents agreed to low ICT literacy skills as a difficulty, while $53(26.2 \%)$ respondents complained of financial constraint. In addition, inaccessibility of some databases was a problem experienced by $75(36.2 \%)$ respondents, while $31(14.8 \%)$ respondents agreed to the problem of inexperienced staff. This has been supported in literature by [8]. The difficulties encountered while using e-resources are shown in Table 4 below.

Table 4. Attitudes and perception of undergraduate students towards e-resources use.

\begin{tabular}{cccccc}
\hline Attitudes and perception of undergraduate students & $\begin{array}{c}\text { Strongly } \\
\text { disagree }\end{array}$ & Disagree & Neutral & $\begin{array}{c}\text { Agree } \\
\text { Strongly } \\
\text { agree }\end{array}$ \\
E-Resources are readily available for use & $15(7 \%)$ & $19(8.8 \%)$ & $59(27.4)$ & $89(41.4 \%)$ & $33(15.3 \%)$ \\
E-Resources are easy to use & $13(6.1 \%)$ & $42(19.6 \%)$ & $61(28.5 \%)$ & $72(33.6 \%)$ & $26(12.1 \%)$ \\
E-Resources require technical know-how to understand & $7(3.3 \%)$ & $18(8.6 \%)$ & 50() $23.8 \%$ & $100(47.6 \%)$ & $35(16.7 \%)$ \\
E-Resources are readily accessible for use & $10(4.7 \%)$ & $25(11.8 \%)$ & $59(27.8 \%)$ & $90(42.5 \%)$ & $28(13.2 \%)$ \\
ICT infrastructure is an expensive venture & $11(5.4 \%)$ & $28(13.7 \%)$ & $69(33.7 \%)$ & $70(34.1 \%)$ & $27(13.2 \%)$ \\
I have phobia for the use of e-resources & $56(26.5 \%)$ & $64(30.3 \%)$ & $41(19.4 \%)$ & $34(16.1 \%)$ & $16(7.6 \%)$ \\
I feel dizzy when using e-resources & $64(30.2 \%)$ & $67(31.6 \%)$ & $43(20.3 \%)$ & $25(11.8 \%)$ & $13(6.1 \%)$ \\
The use of e-resources can negatively affect eyesight & $21(9.8 \%)$ & $34(15.9 \%)$ & $61(28.5 \%)$ & $60(28.0 \%)$ & $38(17.8 \%)$ \\
\hline
\end{tabular}


Table 5. Difficulties encountered while using electronic resources.

\begin{tabular}{|c|c|c|c|c|c|c|}
\hline & Problems & $\begin{array}{l}\text { Strongly } \\
\text { Disagree }\end{array}$ & Disagree & Neutral & Agree & $\begin{array}{l}\text { Strongly } \\
\text { Agree }\end{array}$ \\
\hline A & Too much information on the Internet & $21(9.8 \%)$ & $32(15.0 \%)$ & $37(17.3 \%)$ & $67(31.3 \%)$ & $57(26.6 \%)$ \\
\hline b. & Lack or poor search skill & $21(9.9 \%)$ & $61(28.6 \%)$ & $49(23.0 \%)$ & $51(23.9 \%)$ & $31(14.6 \%)$ \\
\hline c. & High cost of Internet access & $12(5.6 \%)$ & $32(15.0 \%)$ & $43(20.2 \%)$ & $73(34.3 \%)$ & $53(24.9 \%)$ \\
\hline d. & Power outage & $19(9.0 \%)$ & $42(20.0 \%)$ & $54(25.7 \%)$ & $64(30.5 \% 0$ & $31(14.8 \%)$ \\
\hline e. & Slow downloading & $17(8.1 \%)$ & $23(10.9 \%)$ & $49(23.2 \% 0$ & $68(32.2 \%)$ & $54(25.6 \%)$ \\
\hline f. & Inexperienced staff & $17(8.1 \%)$ & $54(25.8 \%)$ & $69(33.0 \%)$ & $38(18.2 \%)$ & $31(14.8 \%)$ \\
\hline g. & Inaccessibility of some databases & $7(3.4 \%)$ & $33(15.9 \%)$ & $62(30.0 \%)$ & $75(36.2 \%)$ & $30(14.5 \%)$ \\
\hline h. & Inadequate computer workstations & $13(6.2 \%)$ & $34(16.25)$ & $59(28.1 \%)$ & $69(32.9 \%)$ & $35(16.7 \%)$ \\
\hline i. & $\begin{array}{l}\text { Low Information and Communication } \\
\text { Technology (ICT) literacy skills }\end{array}$ & $21(9.9 \%)$ & $47(22.1 \%)$ & $62(29.1 \%)$ & $55(25.8 \%)$ & $28(13.1 \%)$ \\
\hline j. & My religion does not support the use of the internet & $104(48.4 \%)$ & $64(29.8 \%)$ & $27(12.6 \%)$ & $10(4.7 \%)$ & $10(4.7 \%)$ \\
\hline $\mathrm{k}$. & $\begin{array}{c}\text { Inadequate Information and } \\
\text { Communication Technology (ICT) facilities }\end{array}$ & $24(11.3 \%)$ & $58(27.4 \%)$ & $58(27.4 \%)$ & $57(26.9 \%)$ & $15(7.1 \%)$ \\
\hline 1. & Financial constraint & $21(10.4 \%)$ & $35(17.3 \%)$ & $61(30.2 \%)$ & $53(26.2 \%)$ & $32(15.8 \%)$ \\
\hline
\end{tabular}

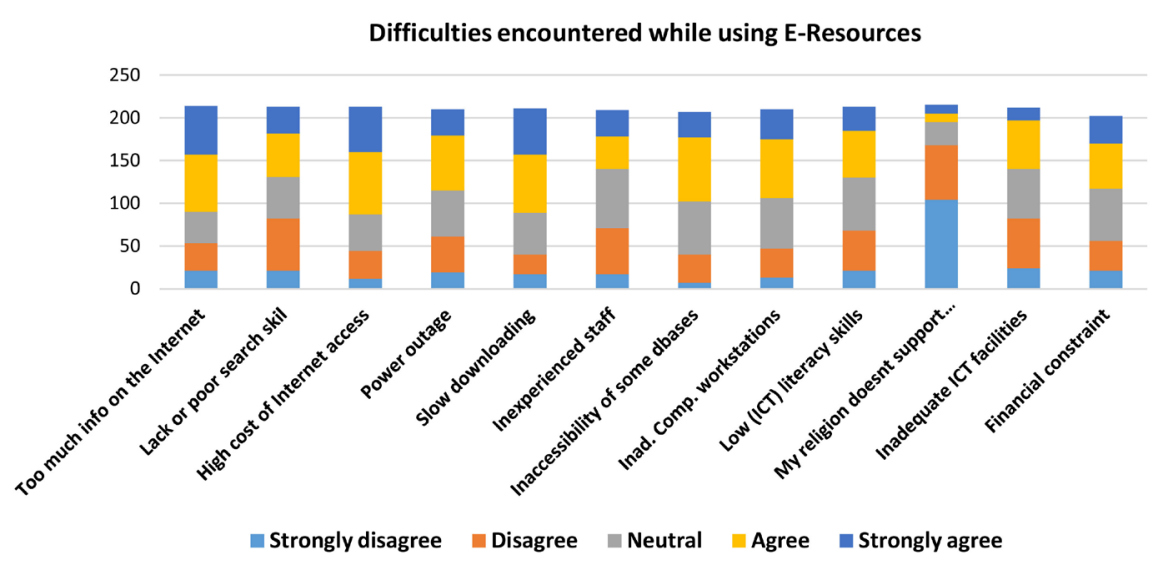

Figure 6. Chart showing difficulties encountered while using E-Resources.

\section{Conclusions}

This section highlights the attitudes and perception on electronic resources use among undergraduate students. As previously reported, many undergraduate students possess low levels of ICT literacy skills on their utilization of e-information resources, as depicted. The outcomes of this study revealed that most of the surveyed UFH and RU respondents possess low frequency levels in their utilization of electronic information resources, for example, Table 1 indicated that JSTOR 94 (63.9\%), EbscoHost 88 (59.1\%), OARE 98 (71.0\%), DOAJ 81 (57.0\%), AJOL 92 (67.2\%) ScienceDirect 91 (46.9\%), ERIC 83 (60.1\%), SAGE 77 (52.7\%), PUBMED CENTRAL 85 (61.2\%), CD-ROMs 52 (34.0\%) and OPAC 40 (24.7\%), HINARI 101 (71.6\%) the respondents never used the aforementioned software respectively. On the contrary, $34(18.1 \%)$ and $29(15.6 \%)$ of the respondents af- 
firmed that they use the E-Journals and E-books every time, this is because they make use of the e-resources to do assignments and obtain relevant literature for their coursework and dissertations. Also, in the course of the in-depth research interview, most of the interviewees make use of CD-ROMs, E-JOURNALS and E-books to do their school assignments. The findings support the assertion that the attitudes and perception of the respondents negatively affect their use of the e-resources because they do not see any need to utilize other e-resources such as e-journals, CD-ROMs and e-books. Previous reports have identified the attitudes and perception of respondents to e-resource use. At this juncture, it is important to state that positive attitudes and perceptions on e-resource use results in the utilization of the e-resources. From the foregoing, several factors contribute to the attitudes and perception of undergraduate students to e-resource use, such as interest, awareness, beliefs, acceptance and adoption of technology. The results from the study depict that that a preponderance of students graduate from HEIs lacking essential skills to cope with the challenges posed by the larger ICT-compliant society. In the same vein, scholars also noted that most users embrace the benefits of utilization of e-information resources over printed ones, and this brought about the attitudes and perception of the respondents in favor of e-journals, CD-ROMs and e-books. According to the theories identified for this study (TAM, DOI and TRA) Correspondingly, as illustrated in Figure 1 before an electronic resource is utilized, there must be awareness and acceptance of the resource, hence, the perceived usefulness is dependent on the awareness of electronic resources, thereby resulting in the behavioral intention to utilize e-information resources. This explains further that the negligence of the undergraduate students on their utilization of e-information resources depends on their perception of and attitudes to the use of the e-resources, which is still centered on perceived usefulness.

The findings from Table 4 revealed that 100 (47.6\%) respondents stated that e-resources require technical know-how to understand. In support of this, as analyzed in Table 5, 57 (26.6\%) respondents encountered too much information on the Internet, in addition to 53 (24.9\%) respondents, who complained about the high cost of Internet access. Furthermore, 35 (16.7\%) respondents were of the opinion that there were inadequate computer workstations, this viewpoint also aligns with $55(25.8 \%)$ respondents, who agreed to low ICT literacy skills as a difficulty, and $53(26.2 \%)$ respondents complained of financial constraint. In addition, inaccessibility of some databases was a problem experienced by 75 (36.2\%) respondents, while 31 (14.8\%) respondents agreed to the problem of inexperienced staff.

\section{Recommendations}

In view of the above findings, the study made specific recommendations on Determinant of undergraduate students' attitude and perception towards the use of electronic information resources (EIRs) among selected universities in East- 
ern Cape, South Africa. Therefore, based on the findings of this study, the following recommendations are made:

There is a necessity for the motivation and drive on the use and benefits of E-resources among undergraduate students through training and re-training, seminars, and workshops, since attitudinal behavior/perception analysis revealed a moderate behavior amongst the sampled students.

There is a need for intervention focusing on the application of some E-resources and software where the students are ranked low.

The universities should persistently improve orientation of students on the use of all the numerous e-resources in the universities.

More computers should be offered in the universities, the students should be trained in the use of electronic resources.

ICT literate academia should be appointed at the resource unit of the universities to deal with technical problems.

Provision of electronic databases, which will help to address the difficulties encountered in online internet environments.

\section{Conflicts of Interest}

The authors declare no conflicts of interest regarding the publication of this paper.

\section{References}

[1] Cull, B. (2015) Time for Reflection?: Digital Text and the Emerging Paper Divide. Against the Grain, 27, Article 12. https://doi.org/10.7771/2380-176X.6994

[2] Estelle, L. (2016) What Students Told Us about Their Experiences and Expectations of Print and e-Books. Insights, 29, 31-36. https://doi.org/10.1629/uksg.281

[3] Kurata, K., Ishita, E., Miyata, Y. and Minami, Y. (2017) Print or Digital? Reading Behavior and Preferences in Japan. Journal of the Association for Information Science and Technology, 68, 884-894. https://doi.org/10.1002/asi.23712

[4] Biasutti, M. and Heba, E.D. (2012) Using Wiki in Teacher Education: Impact on Knowledge Management Processes and Student Satisfaction. Computers \& Education, 59, 861-872. https://doi.org/10.1016/j.compedu.2012.04.009

[5] Mai, J.E. (2016) Looking for Information: A Survey of Research on Information Seeking, Needs, and Behavior. Emerald Group Publishing, London.

[6] Chang, S.S. and Chen, K.N. (2011) University Librarians Respond to Changes in Higher Education: Example of a Medical School. New Library World, 112, 425-445. https://doi.org/10.1108/03074801111182021

[7] Chaudhuri, S.K. (2012) Fair Use vs. Copyright Non-Compliance among the Academic Community in Universities of Developing Nations. International Journal of Digital Library Services, 2, 135-147.

[8] Gakibayo, A. and Okello-Obura, C. (2013) Electronic Information Resources Utilization by Students in Mbarara University Library. Library Philosophy and Practice.

[9] Owolabi, S. and Okocha, F. (2016) Utilization of Information Resource by Undergraduate Students of University of Ibadan. Journal of Education and Practice, 7, 30-36.

[10] Veletsianos, G. and Kimmons, R. (2013) Scholars and Faculty Members' Lived Ex- 
periences in Online Social Networks. The Internet and Higher Education, 16, 43-50. https://doi.org/10.1016/j.iheduc.2012.01.004

[11] Brown, J.S. and Duguid, P. (2017) The Social Life of Information: Updated, with a New Preface. Harvard Business Review Press, Cambridge, MA.

[12] Teranishi, R.T., Suárez-Orozco, C. and Suárez-Orozco, M. (2015) In the Shadows of the Ivory Tower: Undocumented Undergraduates and the Liminal State of Immigration Reform.

[13] Thomas, G. (2017) How to Do Your Research Project: A Guide for Students. Sage, London.

[14] Bender, T. (2012) Discussion-Based Online Teaching to Enhance Student Learning: Theory, Practice and Assessment. Stylus Publishing, LLC, New York.

[15] Margaryan, A., Littlejohn, A. and Vojt, G. (2011) Are Digital Natives a Myth or Reality? University Students' Use of Digital Technologies. Computers \& Education, 56, 429-440. https://doi.org/10.1016/j.compedu.2010.09.004

[16] Bagudu, A.A. and Sadiq, H. (2013) Students 'Perception of Digital Library Services: A Case Study of International Islamic University, Malaysia. Library Philosophy \& Practice.

[17] Rockinson-Szapkiw, A.J., Courduff, J., Carter, K. and Bennett, D. (2013) Electronic versus Traditional Print Textbooks: A Comparison Study on the Influence of University Students' Learning. Computers \& Education, 63, 259-266.

https://doi.org/10.1016/j.compedu.2012.11.022

[18] Vigdor, J.L., Ladd, H.F. and Martinez, E. (2014) Scaling the Digital Divide: Home Computer Technology and Student Achievement. Economic Inquiry, 52, 1103-1119. https://doi.org/10.1111/ecin.12089

[19] Wang, S.K., Hsu, H.Y., Campbell, T., Coster, D.C. and Longhurst, M. (2014) An Investigation of Middle School Science Teachers and Students Use of Technology Inside and Outside of Classrooms: Considering Whether Digital Natives Are More Technology Savvy than Their Teachers. Educational Technology Research and Development, 62, 637-662. https://doi.org/10.1007/s11423-014-9355-4

[20] Cooper, J.D., Robinson, M.D., Slansky, J.A. and Kiger, N.D. (2014) Literacy: Helping Students Construct Meaning. Cengage Learning, London.

[21] Rennie, F. and Morrison, T. (2013). E-Learning and Social Networking Handbook: Resources for Higher Education. Routledge, London. https://doi.org/10.4324/9780203120279

[22] Ofen, N. and Shing, Y.L. (2013) From Perception to Memory: Changes in Memory Systems across the Lifespan. Neuroscience \& Biobehavioral Reviews, 37, 2258-2267. https://doi.org/10.1016/j.neubiorev.2013.04.006

[23] Alkhanak, S.A.A.K. and Azmi, I.A.G. (2011) University Students Information Technology Experience and Its Role towards e-Learning Orientation. New Educational Review, 24, 231-242.

[24] Okiki, O.C. (2012) Electronic Information Resources Awareness, Attitude and Use by Academic Staff Members of University of Lagos, Nigeria.

[25] Radjagopal, V. (2012) Users' Attitudes and Approaches towards e Resources and Services in the Academic Libraries of Puducherry Union Territory.

[26] Bashorun, M.T., Jain, P., Sebina, P.M. and Kalusopa, T. (2016) Determinants of Adoption and Use of Open Access Publishing by Academic Staff in Nigeria Universities

[27] Thanuskodi, S. (2012) Use of E-Resources by the Students and Researchers of Fa- 
culty of Arts, Annamalai University. International Journal of Library Science, 1, 1-7. https://doi.org/10.5923/j.library.20120101.01

[28] Simon, N.S. and Johnson, S.M. (2015) Teacher Turnover in High-Poverty Schools: What We Know and Can Do. Teachers College Record, 117, 1-36.

[29] Egberongbe, H.S. (2011) The Use and Impact of Electronic Resources at the University of Lagos.

[30] Ozoemelem, O.A. (2009) Use of Electronic Resources by Postgraduate Students of the Department of Library and Information Science of Delta State University, Abraka, Nigeria. Library Philosophy and Practice, 11, 1-23.

[31] Blandy, S.G. and Libutti, P.O.B. (1995) As the Cursor Blinks: Electronic Scholarship and Undergraduates in the Library. 